www. revist a d y o.com

\title{
Organizational best practices in packaging design. An analysis in perfumery and clean- ing products
}

Jesús García-Arca, A. Trinidad González-Portela, J. Carlos Prado-Prado

Recibido: 12 de Octubre de 2018 / Aceptado: 19 de Octubre de 2018

\begin{abstract}
Packaging is a key element that supports and promotes improvements, innovations and sustainability in turbulent global supply chains. This perspective has brought about the concept "Packaging Logistics" and, more recently, "Sustainable Packaging Logistics" (SPL). This paper has two aims. First, it will identify the main organizational best practices in packaging design linked to SPL deployment, based on a general literature review. Second, it will describe a study into 90 Spanish manufacturers of perfumery and cleaning products in order to explore whether the implementation of these practices could improve sustainable performance in supply chain management. The results indicate that further development of many of these best practices could actively help increase overall performance.
\end{abstract}

\section{Keywords}

Packaging; Logistics; Sustainability; Perfumery; Cleaning products.

\section{Background}

In turbulent global markets, companies and supply chains should increase efforts to improve their competitiveness (Christopher, 2016). At the same time, society, governments and other stakeholders are increasingly concerned about how companies and supply chains are acting ethically to develop the concept of sustainability and put it into practice ${ }^{1}$.

Beske and Seuring (2014) mention the potential of promoting sustainable supply chains, in terms of environmental, economic and social development, as they save resources and reduce waste and pollution. When promoting sustainable efficiency in supply chains, companies should design and implement improvements, actions and polices that would affect both operational aspects and strategic decisions.

At the same time, the scientific literature usually associates the concept of Best Practice (BP) with any actions or policies that lead to or facilitate improved company or supply chain performance. (Davies and Kochlar, 2002). Although

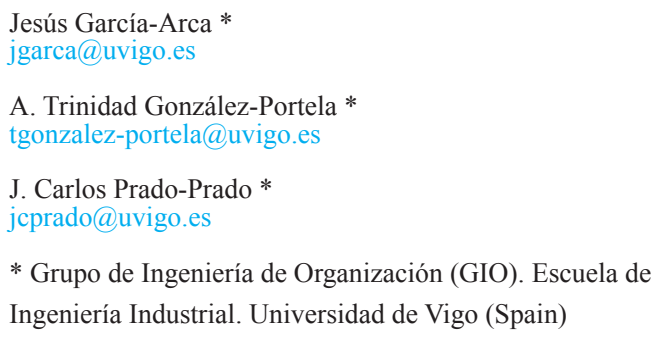

this idea stemmed from a more production-oriented sphere (World Class Manufacturing; Hayes and Wheelwright, 1984), it has slowly spread to all the other processes in the supply chain to promote a more global view linked to the deployment of sustainability (Pagell and Wu, 2009; Mollenkopf et al., 2010; Mejías et al., 2016).

Many authors and literature sources consider packaging as one of the overarching elements that support an efficient and sustainable supply chain (for example, Saghir, 2002; Azzi et al., 2012; García-Arca et al., 2014; Hellström and Olsson, 2017; García-Arca et al., 2017, Palsson, 2018; Regattieri et al., 2019). Indeed, some authors identify suitable packaging design as an unavoidable best practice in sustainable supply chain development (Mejías et al., 2016).

Therefore, a comprehensive view, taking in packaging, supply chain and sustainability, has led to the conceptual and applied development of the "Packaging Logistics" (Saghir, 2002) approach and, more recently, "Sustainable Packaging Logistics" (SPL; García-Arca et al., 2014). The latter authors define SPL as:

The process of designing, implementing, and controlling the integrated packaging, product and supply chain systems in order to prepare goods for safe, secure, efficient and effective handling, transport, distribution, storage, retailing, consumption, recovery, reuse or disposal, and related information, with a view to maximizing social and consumer value, sales, and profit from a sustainable perspective, and on a continuous adaptation basis”.

\footnotetext{
${ }^{1}$ The concept of sustainability appeared for the first time in The Brundtland Report (1987), which identified three fundamental pillars for developing it: economic, social and environmental.
} 
Thus, the main objective and research question of this paper is to explore to what extent promotion and implementation of organizational best practices in packaging design, framed within an SPL approach, actively help improve the sustainable performance of supply chains.

The paper is structured into two stages. Firstly, a literature review is used to identify and justify best practices related to packaging design from the perspective of sustainability and supply chain efficiency. Then, an empirical study in the perfumery and cleaning products sector provides analysis as to whether increased deployment of these best practices actively contributes to improvement in supply chain sustainability.

The main motivation behind this paper originates from the fact that although the literature contains broad consensus on the important contribution of packaging in deploying sustainability throughout the supply chain, it has scarcely been dealt with at a quantitative and organizational level (Azzi et al., 2012; Pålsson, 2018; Regattieri et al., 2019).

Thus, recent studies mainly focus on case-studies (Hellström and Nilsson, 2011; Kye et al., 2013; Accorsi et al., 2014; García-Arca et al., 2013; García-Arca et al., 2014; Pålsson and Hellström, 2016; Rundh, 2016; Sohrabpour et al., 2016) or product comparisons (Svanes et al., 2010; Vernuccio et al. 2010; Albretch et al., 2013; Gelici-Zeco et al., 2013; Wever and Vogtländer, 2013; Bertoluci et al., 2014; García-Arca et al., 2016, 1; Hellström and Olsson, 2017), rather than analysis of the packaging design process in a broader sample of companies such as the one in this paper (with the exception of the work by García-Arca et al. (2016, 2) and García-Arca et al.(2017)).

This paper makes a novel contribution by focusing on deployment of the concept of best practice applied to the packaging design process from a quantitative perspective linked to improved sustainability. At the same time, the empirical study moves into a new sector, as no mention has been found in the literature of either qualitative or quantitative approaches in this type of packaging from an SPL perspective.

\section{Organizational best practices for im- proving packaging design}

Packaging can be seen as one of the key elements that support the adoption of sustainable strategies throughout the supply chain. However, improved supply chain performance should be linked to the deployment of actions and policies (best practices) that positively impact on all three pillars of sustainability (economic, environmental and social) rather than only one or two of them. In such a context, integrated design of packaging, product and supply chain could actively contribute to putting the three pillars into practice (Azzi et al., 2102; Grönman et al., 2013; Molina-Besch and Pålsson, 2014; García-Arca et al., 2017; Hellström and Olsson, 2017):
On a social level, packaging design can be seen from several viewpoints: the supply of information that is transparent, honest, clear and true; adaptation of the uses and dose/serving sizes to the needs of different customers (for example, senior citizens or people with disabilities); a guarantee of safe use (Vernuccio et al., 2010; Azzi et al., 2012; García-Arca et al., 2017; Hellström and Olsson, 2017; Palsson, 2018; Regattieri et al., 2019).

On an economic level, packaging not only promotes increased sales by reinforcing product differentiation, it can also decrease costs by improving the efficiency of logistics processes such as purchases, supplying, packing, handling, storing and transport as well as reduce losses (Hellström and Saghir, 2007; Sohrabpour et al., 2016). The economic impact of packaging design can not only be direct (typically, packaging purchases and waste management), but also indirect (packing, handling, storage, transport and losses). This indirect relationship explains why many companies may not value some decisions in packaging design as highly as perhaps they should. (García-Arca and Prado-Prado, 2008).

At the same time, minimizing the environmental impact of packaging design could be down to three complementary lines of action: a reduction in packaging waste and raw materials consumption (Svanes et al., 2010; Azzi et al., 2012; Albrecht et al., 2013; Grönman et al., 2013; Molina-Besch and Pålsson, 2014); promotion of returnable packaging, recycling and/or recovery waste from packaging (Grönman et al, 2013); and finally, improved protection of the product aimed at reducing losses (García-Arca et al., 2017). In some cases environmental impact management has been simplified in economic terms by the application of taxes such as the green dot (e.g., European Directive 94/62/EC and its updated version 2004/12/EC).

In order to clarify the three pillars of sustainability in terms of practice and, therefore, supply chain performance, it is necessary to consider packaging as a system comprising three levels (Saghir, 2002): primary or consumer packaging, secondary or transport packaging (usually, boxes) and tertiary packaging (several primary or secondary packages grouped together on a pallet). From a global perspective, the interaction between different levels, needs, priorities and requirements becomes clear once their interdependence is understood and explained.

However, areas, departments and companies throughout the supply chain have different requirements, needs, or priorities with regard to packaging; they will not be distributed homogeneously over the three levels of packaging, and will demand an integrated view of product, packaging and supply chain. Because these different viewpoints exist it is advisable to implement coordinated organizational structures in the packaging design process in order to gain a holistic perspective (Lee and Lye, 2003; Klevas, 2005; Chan et al., 2006; García-Arca and Prado-Prado, 2008; Molina-Besch and Pålsson, 2014; Sohrabpour et al., 2016). 
In this context, the "packaging logistics" approach (Shagir, 2002; Hellström and Saghir, 2007; García-Arca and Prado-Prado, 2008; Palsson and Hellström, 2016; Sohrabpour et al., 2016; Pålsson, 2018; Regattieri et al., 2019) has included the concept of integrating both product design and packaging design into supply chain management and design (direct and reverse). Special emphasis is not only placed on the repercussions in terms of organization and efficiency, but also on strategic repercussions that promote competitive improvement.

The new, expanded version of this initial concept, "Sustainable Packaging Logistics" (SPL; García-Arca et al., 2014; see definition in Background section), makes explicit mention of supply chain logistics processes, sustainability and the dynamic perspective of packaging design decisions. It also underscores the idea of integrating packaging, product and supply chain. Likewise, it strengthens the connection between packaging and improved supply chain performance and, therefore, improved competitiveness.
So, companies could tackle the search for good packaging alternatives by combining the four main decisions to be taken in design: the selection of materials and dimensions, their own structure for the packaging system (relationship between primary, secondary and tertiary packaging) and the aesthetic design of the packaging (text, colors, brand, image, shape and so on). That way, knowledge and special awareness can be generated in the companies and this would incite change, improvement and innovation in their packaging.

Authors such as Saghir (2002), García-Arca and Prado-Prado (2008) and Bramklev (2009) identify three main requirements when designing packaging: the commercial requirement, the logistics requirement and the environmental requirement. In fact, these three major requirements can be broken down into 9 different aspects (see table 1), including the basic one of protecting the product (Verghese et al., 2015; Hellström and Olsson, 2017).

Table 1 Main packaging design requirements (adapted from Azzi et al., 2012; Lindh et al., 2016; Rundh, 2016; Garcia-Arca et al., 2017)

\begin{tabular}{l|l}
\hline Requirement & Main Aim \\
\hline Commercial & Improve differentiation capacity and product attractiveness \\
\hline Protective & Ensure adequate protection to avoid product loss or deterioration \\
\hline Productive & Facilitate productivity and flexibility in packing processes \\
\hline Packaging purchases & Facilitate handling, warehousing and transport processes \\
\hline Environmental & Guarantee packaging purchases and supply \\
\hline Ergonomic & Reduce raw material consumption and waste generation \\
\hline & Ease product handling, including points of sale and consumers \\
\hline
\end{tabular}

The process of selecting the "best packaging" by a company is usually linked to cost reductions and sales improvements. However, this cost reduction approach can be risky if not considered from an overall perspective since "economic" packaging could imply the sacrifice of some of its potential to be "different" and environmentally friendly. This is a design paradox and implies that packaging design demands an assessment system for analyzing and comparing packaging alternatives (Garcia-Arca et al., 2018;1). Thus, more alternatives and selection criteria become available when an integrated and holistic approach to packaging design is considered. All things considered, correct structuring and or- ganization of the packaging design process in a way that is integrated with the design of the product itself and its supply chain is a need that goes beyond the operational sphere as it enters the realm of strategic impacts.

As a result, the adoption of organizational best practices in the packaging design process becomes a key driving force for change, innovation and competitiveness. The challenge is not to implement each adopted practice in isolation, but rather to consider them as an organizational learning process leading to company competitiveness throughout supply chains. 
In order to identify the potential selection of best practices in packaging design from a sustainable supply chain perspective, a systematic three-step literature review was undertaken. The first step was to identify papers in scientific sources (academic journals, conference papers and book chapters) published between 2000 and 2018. The literature review search criteria included the combined terms: "packaging", "logistics", "supply chain", "product design" and "sustainable performance". The second step was to analyze the abstracts and contents of these papers to find these best practices.

As steps one and two gave a selection based strictly on influential scientific journals, which could have left out some other significant sources of material relevant to the topic of study, the authors added a final step to include additional material of a less scientific nature, including reports, information coming from reports and recommendations developed by companies and organizations.

The three-step literature review led to a selection of 32 best practices in packaging design (see table 2). This selection of best practices was grouped into four categories following the main pillars and drivers proposed by García-Arca and Prado-Prado (2008), García-Arca et al. (2017) and García-Arca et al. $(2018 ; 1)$ in relation to SPL implementation.

- Structuring best practices (6). These support the development of a coordinated structure for packaging design, both internally in each company and externally throughout the supply chain (García-Arca and Prado-Prado, 2008; Olander-Roase and Nilsson, 2009; Molina-Besch and Pålsson, 2014; Sohrabpour et al., 2016; García-Arca et al., 2017).
- Measurement best practices (11). The adoption of a system that measures and values the pros and cons of each alternative in packaging is needed to select the "best" one objectively (Gelici-Zeko et al. 2012; Kye et al. 2013; García-Arca et al. 2014; Hellström and Olsson, 2017; Olsmats and Dominic, 2003; García-Arca et al., 2014; García-Arca et al. $(2018,1)$.

- $\quad$ Standardization best practices (4). Packaging Design could and should be considered a process. Thus, as a process, it could and should be defined, standardized and documented, including the information needed for design and implementation (García-Arca and Prado-Prado, 2008; AECOC, 2012; García-Arca et al., 2016, 2).

- $\quad$ Pro-active best practices (11). The adoption of SPL could generate a culture of change, improvement and innovation within companies which could impact on overall supply chain performance. The improvements in packaging design adopted by some companies could illustrate and stimulate the need for changes in other companies (Hellström and Nilsson, 2011; AECOC, 2012; Kye et al., 2013; Pålsson and Hellström, 2016; García-Arca et al., 2017; additional contributions from different packaging, environment, and logistics related institutions, particularly, ECOEMBES (www.ecoembes.com), ECR-EUROPE (www.ecr-community.org) or EUROPEN (www.europen-packaging.eu). 
Jesús García-Arca et al. / Dirección y Organización 68 (2019) 5-19

Table 2 Selection of organizational best practices in packaging design

\begin{tabular}{|c|c|c|}
\hline & Best practice & Explanation of the best practice \\
\hline \multirow[t]{6}{*}{$\begin{array}{l}\text { Structuring best } \\
\text { practices }\end{array}$} & $\begin{array}{l}\text { Internal coordination in } \\
\text { packaging design }\end{array}$ & $\begin{array}{l}\text { The multi-faceted nature of design requirements means that decisions about them can } \\
\text { fall to different areas or departments within each company. If this is the case, then it } \\
\text { is advisable for collaboration and coordination to be bolstered between all the affected } \\
\text { areas or departments }\end{array}$ \\
\hline & $\begin{array}{l}\text { Integration of packaging } \\
\text { and product design }\end{array}$ & $\begin{array}{l}\text { Packaging design and product design are closely related, which means suitable integra- } \\
\text { tion of both will contribute to global solutions that are efficient and sustainable }\end{array}$ \\
\hline & $\begin{array}{l}\text { Coordination with packag- } \\
\text { ing suppliers }\end{array}$ & $\begin{array}{l}\text { The multi-faceted nature of design requirements mean that it is advisable to bolster } \\
\text { collaboration and coordination among all affected companies along the supply chain, } \\
\text { particularly with the packaging suppliers }\end{array}$ \\
\hline & Coordination with retailers & $\begin{array}{l}\text { Likewise, collaboration and coordination in packaging design should be strengthened } \\
\text { with retailers }\end{array}$ \\
\hline & $\begin{array}{l}\text { Coordination with raw ma- } \\
\text { terials/ components sup- } \\
\text { pliers }\end{array}$ & $\begin{array}{l}\text { Likewise, collaboration and coordination should be strengthened with raw materials/ } \\
\text { components suppliers }\end{array}$ \\
\hline & $\begin{array}{l}\text { Coordination with other } \\
\text { companies to make joint } \\
\text { packaging purchases }\end{array}$ & $\begin{array}{l}\text { Going further, an additional collaboration and coordination alternative is linked to joint } \\
\text { purchase of packaging formats and materials with other companies (even with the com- } \\
\text { petition) }\end{array}$ \\
\hline
\end{tabular}


Jesús García-Arca et al. / Dirección y Organización 68 (2019) 5-19

Table 2 (continuation)

\begin{tabular}{|c|c|c|}
\hline \multirow[t]{11}{*}{$\begin{array}{l}\text { Measurement best } \\
\text { practices }\end{array}$} & Packaging purchases costs & $\begin{array}{l}\text { Implementation of an assessment system for the supplies of packaging materials would } \\
\text { enable the economic comparison among alternatives in terms of type, size and quality } \\
\text { of these materials }\end{array}$ \\
\hline & Packing costs & $\begin{array}{l}\text { Implementation of an assessment system for valuing packing costs would enable meas- } \\
\text { urement in economic terms of the impact of packaging design decisions on the effi- } \\
\text { ciency of production processes. For example, measurement of the impact on setups and } \\
\text { productivity or rejects generated in these processes }\end{array}$ \\
\hline & Internal logistic costs & $\begin{array}{l}\text { Implementation of an assessment system for the company's internal logistics costs en- } \\
\text { ables economic measurement of the impact packaging design decisions have on the } \\
\text { efficiency and sustainability of the supply chain's internal stages. For example, meas- } \\
\text { urement of the impact on handling, storing, and transport processes within the company }\end{array}$ \\
\hline & External logistic costs & $\begin{array}{l}\text { Implementation of an assessment system for the company's external logistics costs en- } \\
\text { ables economic measurement of the impact packaging design decisions have on the } \\
\text { efficiency and sustainability of the supply chain's external stages. For example, meas- } \\
\text { urement of the impact on handling, storing and transport processes up and downstream } \\
\text { in the supply chain }\end{array}$ \\
\hline & Packaging waste costs & $\begin{array}{l}\text { Implementation of an assessment system for the environmental impact of packaging de- } \\
\text { sign decisions. This enables comparison of different design alternatives. In practice, the } \\
\text { economic perspective is simplified by assessing the cost of green dot compliance, which } \\
\text { varies according to the class of packaging materials, their quantity and their quality }\end{array}$ \\
\hline & Packaging Scorecard & $\begin{array}{l}\text { The multi-faceted nature of packaging design requirements has encouraged the imple- } \\
\text { mentation of different assessment methods that combine qualitative and quantitative } \\
\text { aspects from different perspectives (social, environmental and economic).The most } \\
\text { widespread of these methods is "Packaging Scorecard", made popular by companies } \\
\text { such as IKEA and Walmart (Olsmats and Dominic, 2003) }\end{array}$ \\
\hline & $\begin{array}{l}\text { Life Cycle Assessment } \\
\text { (LCA) }\end{array}$ & $\begin{array}{l}\text { The most commonly used system for measuring environmental impact (ISO 14040; } \\
\text { 2006). This technique measures, basically, the carbon footprint generated by the prod- } \\
\text { uct, including its components and, particularly, the packaging }\end{array}$ \\
\hline & Benchmarking & $\begin{array}{l}\text { Suitable packaging design could be considered as a "silent salesman" to highlight some } \\
\text { features of the products that promote differentiation. Thus, a way to measure the com- } \\
\text { mercial impact of one packaging design is to adopt comparative tests between competi- } \\
\text { tors' packaging alternatives, also known as "Benchmarking" techniques (Gelici-Zeko et } \\
\text { al, 2012). These tests are usually performed at the primary packaging level }\end{array}$ \\
\hline & "Palletization Software" & $\begin{array}{l}\text { There are software tools that help packaging design by searching for improved logistics } \\
\text { efficiency within the supply chain by means of different heuristics or metaheuristics } \\
\text { techniques (often called "Palletization software") }\end{array}$ \\
\hline & $\begin{array}{l}\text { "Space Management Soft- } \\
\text { ware" }\end{array}$ & $\begin{array}{l}\text { There are other software tools ("Space Management Software") devoted to improving } \\
\text { both efficiency in handling and product differentiation on the shelves at points of sale. } \\
\text { Programs of this type seek to connect the brand image of the product with the rational- } \\
\text { ization of the resources used in the shops by comparing different planograms in order } \\
\text { to maximize sales and profits }\end{array}$ \\
\hline & $\begin{array}{l}\text { Monitoring system for rede- } \\
\text { signing packaging }\end{array}$ & $\begin{array}{l}\text { In this design process, it could be helpful to implement a monitoring system for rede- } \\
\text { signing old packaging in order to adapt it to new needs and even to detect new opportu- } \\
\text { nities (e.g., new materials or new packing systems) }\end{array}$ \\
\hline
\end{tabular}


Jesús García-Arca et al. / Dirección y Organización 68 (2019) 5-19

Table 2 (continuation)

\begin{tabular}{|c|c|c|}
\hline \multirow[t]{5}{*}{$\begin{array}{l}\text { Standardization } \\
\text { best practices }\end{array}$} & $\begin{array}{l}\text { Documentation of the pack- } \\
\text { aging design process }\end{array}$ & $\begin{array}{l}\text { Documentation of the packaging design process (including activities, the people re- } \\
\text { sponsible and deadlines) helps to highlight organizational inefficiencies that could } \\
\text { be caused by a lack of understanding of the design requirements, delays, and/or extra } \\
\text { charges when selecting alternatives }\end{array}$ \\
\hline & $\begin{array}{l}\text { Documentation of palletiza- } \\
\text { tion and packaging patterns }\end{array}$ & $\begin{array}{l}\text { The documentation of palletization and packaging patterns (placement of products in } \\
\text { packaging and pallets) eases decision-making related to selection of alternatives as it } \\
\text { searches for inefficiencies in volume occupation or in the level of standardization of } \\
\text { packaging formats }\end{array}$ \\
\hline & $\begin{array}{l}\text { Packaging materials speci- } \\
\text { fications }\end{array}$ & $\begin{array}{l}\text { The availability of documentation of some technical features related to packaging eases } \\
\text { decision-making related to selection of alternatives, the possibilities of standardization } \\
\text { or the efficiency of packaging purchases }\end{array}$ \\
\hline & RAL adoption & $\begin{array}{l}\text { The Spanish AECOC organization (www.aecoc.es), when developing the ECR (Effi- } \\
\text { cient Consumer Response) initiative, promoted a series of recommendations among } \\
\text { manufacturers, retailers and third-party logistics (3PL) in order to improve efficiency in } \\
\text { supply chain operation. In Spain these AECOC logistics recommendations are known } \\
\text { by their Spanish acronym RAL. }\end{array}$ \\
\hline & & $\begin{array}{l}\text { They include specific recommendations concerning packaging (AECOC, 2012), par- } \\
\text { ticularly with reference to palletization efficiency levels of the unit loads on EUR pal- } \\
\text { lets, the dimensions of packaging multiples or submultiples with the } 600 * 400 \mathrm{~mm} \text { mod- } \\
\text { ule, (ISO } 3676 \text { (2012) and ISO } 3394 \text { (2012)), the definition of the height of unit and the } \\
\text { maximum weight of boxes and the pallet }\end{array}$ \\
\hline \multirow[t]{11}{*}{$\begin{array}{l}\text { Active best } \\
\text { practices }\end{array}$} & Dimensional changes & $\begin{array}{l}\text { Resizing the packaging can help reduce material and, consequently, waste. It also eases } \\
\text { improvement of the product's volumetric and subsequent logistical efficiency, making } \\
\text { the packaging and packing processes more productive }\end{array}$ \\
\hline & Material changes & $\begin{array}{l}\text { These changes can help simplify the number of materials used (economies of scale), } \\
\text { employ cheaper materials, or include the use of recyclable or recoverable materials }\end{array}$ \\
\hline & $\begin{array}{l}\text { Amount of product per } \\
\text { packaging }\end{array}$ & $\begin{array}{l}\text { The changes in the quantity of product per packaging can help reduce consumption of } \\
\text { materials and generation of packaging waste }\end{array}$ \\
\hline & Change in packing process & $\begin{array}{l}\text { Switching from a manual to an automatic process (or vice versa) can help lower pro- } \\
\text { duction costs, as well as decrease product rejection/deterioration, and resource con- } \\
\text { sumption }\end{array}$ \\
\hline & $\begin{array}{l}\text { Change in the number of } \\
\text { items per each level of } \\
\text { packaging }\end{array}$ & $\begin{array}{l}\text { Redesigning the link between primary, secondary and tertiary packaging can help im- } \\
\text { prove efficiency (handling, warehousing and transport), by rationalizing materials and } \\
\text { waste }\end{array}$ \\
\hline & $\begin{array}{l}\text { Dimensional Standardiza- } \\
\text { tion }\end{array}$ & $\begin{array}{l}\text { Dimensional standardization in packaging formats and shapes simplifies the procure- } \\
\text { ment process for packers, providing economies of scale when purchasing. Productivity } \\
\text { can be improved by reducing set-up times }\end{array}$ \\
\hline & Materials Standardization & $\begin{array}{l}\text { Standardizing the material types in the packaging, facilitates procurement and supply- } \\
\text { ing tasks for the packaging manufacturer (economies of scale) }\end{array}$ \\
\hline & Overpacking reduction & $\begin{array}{l}\text { Removing superfluous packaging can help reduce not only purchase, logistics and pro- } \\
\text { ductive costs but also waste }\end{array}$ \\
\hline & Aesthetic changes & $\begin{array}{l}\text { The selection of a suitable text, color, iconography, material or shape can simplify pur- } \\
\text { chasing and recycling costs of packaging, promoting sales through better communica- } \\
\text { tion of the product's features }\end{array}$ \\
\hline & Returnable packaging & $\begin{array}{l}\text { The use of returnable packaging instead of single-use packaging can help reduce overall } \\
\text { logistics costs, including purchases costs, resources consumption and waste generation } \\
\text { (typically, secondary or tertiary packaging) }\end{array}$ \\
\hline & $\begin{array}{l}\text { SRPs (Shelf Ready Pack- } \\
\text { aging) }\end{array}$ & $\begin{array}{l}\text { SRP is a group of primary packages in a secondary or tertiary packaging that is easily } \\
\text { ready for exhibition at the point of sale. It not only helps reduce waste but also reduces } \\
\text { material and logistic costs (particularly, handling and product location at point of sale) }\end{array}$ \\
\hline
\end{tabular}




\section{Methodology for empirical analysis}

With regard to the objectives outlined in the background section, this section presents an empirical analysis of companies in order to explore how far deploying organizational best practices in packaging design contributes to improving sustainable performance throughout the supply chain. To achieve this, the authors look into the relationship between achieving better results in terms of sustainability and implementing these organizational best practices.

The authors carried out an exploratory study in Spanish manufacturers of perfumery and cleaning products, where the needs for differentiation, efficiency and sustainability are particularly important. Companies in this sector have clearly varied profiles and supply a wide range of products with highly differing needs from the standpoint of packaging. This amount of variety has enriched the development of the study. In order to put this variety of design requirements into context, an additional research question has been added that analyzes the relationship between the importance placed on each requirement and the improvement in the results at a sustainability level.

The methodology used in this study was based on structured electronic questionnaires featuring the selection of organizational best practices presented in table 2. The Spanish Alimarket database (www.alimarket.es) was used to identify potential companies for the study. The interviewees in each company were mostly logistics/production managers and 90 companies participated in the study. Each selected company was contacted by phone to present the study and request their participation. A follow-up email was then sent containing a link to the online survey which included all the organizational best practices.

The items in the questionnaire were ranked by companies according to their level of importance or implementation. To assess these items, the companies were asked to score the values on a Likert scale where 1 was "poorly valued" and 5 was "highly valued". Data collection via the survey was carried out over 3 months.

Likewise, the Likert scores reported by companies were used to consider the importance of four different aspects of sustainable improvement in supply chains thanks to packaging design (García-Arca et al., 2017). Particularly:

- The increase in sales (economic sustainability).

- The reduction in costs (economic sustainability).

- The improvement in safety and the ease of use of products (social sustainability).

- The reduction of the environmental impact generated by the company and its supply chain (environmental sustainability). In practice, this would reduce resource consumption and the raw materials used, as well as reducing pollution and waste (including losses and product deterioration).

To carry out the analysis in companies, two groups were established based on the "BEST" or "WORST" supply chain performance achieved thanks to their packaging (45 companies in each group). The supply chain performance is statistically different between both groups of companies (p-value: $2.13461 \mathrm{E}-20$ ). The first group included firms with better sustainable performance through packaging design (sum of all assessments in the four aspects of performance). The second group included companies with worse sustainable performance. Likewise, to compare the potential impact of implementing these best practices, the non-parametric Wilcoxon test was applied. This test identifies statistical differences in the mean values of an item between two groups; these differences are considered significant when the p-value is below $0.05\left(^{*}\right)$ or, in a restrictive way, when the p-value is below $0.01(* *)$.

\section{Results}

Research into packaging in perfumery and cleaning product manufacturers shows some evidence that the implementation of organizational best practices in packaging design could contribute to increased supply chain performance in terms of sustainability (see table 3). Clearly, other factors not included in the analysis could also affect performance but, a priori, in the same way in all companies (the best and the worst groups). Thus, the questions about sustainable supply chain performance in the study focus directly on the contribution of the packaging design to this performance. This positive impact is produced across the board for all the best practice categories analyzed although, logically, not individually in all the best practices. In order to analyze the results more thoroughly, this section contains four sub-sections, one for each of the four best practice categories under consideration.

\section{$\underline{\text { Structuring best practices }}$}

At the level of internal structuring of packaging design, the study's preliminary results do not yield significant differences between the two groups (see table 3). Initially, this situation would suggest that both groups place similar importance on internal coordination and collaboration among all areas or departments linked to packaging design, even when done jointly with product design. Indeed, the companies' scores for these two best practices are among the highest.

However, a deeper look at the deployment of these two best practices shows significant differences regarding the importance placed on each of the nine design requisites; specifically, differences have been found in five of them (pro- 
tective, packaging purchases, environmental, ergonomic and communication). This can be seen in figure 1 . This seems to indicate that a greater sensitivity towards a multifunctional view of packaging in a supply chain context is needed to achieve better results in sustainability.

Figure 1 Importance of each packaging design requirement on sustainability

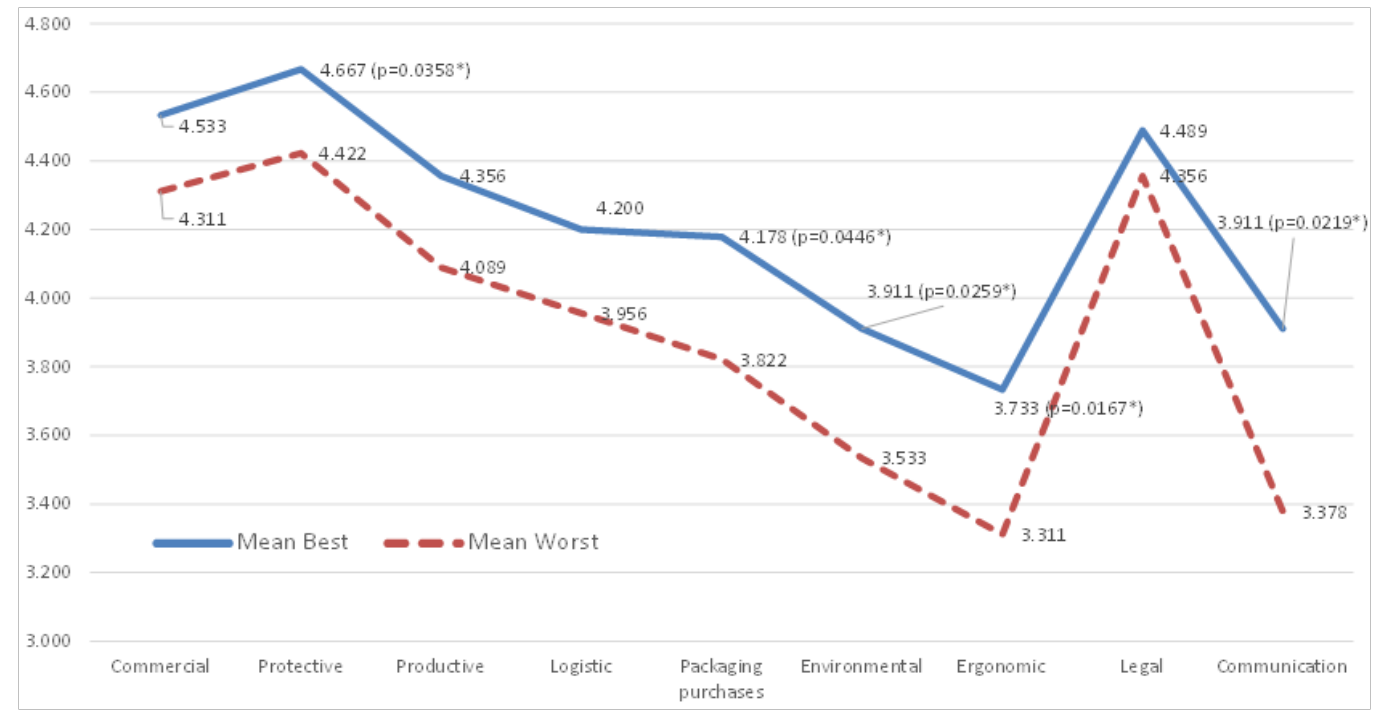

At the same time, the results in the group of structuring best practices partially validates this assumption at an external level (see table 3 ), with packaging suppliers, raw materials suppliers and even other types of companies (including competitors). The exception to this conclusion is at the level of coordination with retailers, where no significant differences have been found between the two groups of companies. The explanation for this could lie in the idea that companies, understanding the impact of certain packaging design decisions, search for collaboration and coordination upstream in the supply chain or even with other types of companies (to achieve economies of scale in packaging purchases).

However, downstream in the supply chain, the situation points to retailer leadership in packaging design that could condition all companies in the same way. Nevertheless, the role the retailers play, leading the process of packaging design, should be analyzed in future research as this study only analyzes the manufacturers' perspective.

\section{Measurement best practices}

In the second group of best practices, there are significant differences in the development of some measurement systems (see table 3 ). Here, it should be pointed out that measurement systems based on costs are more often developed and implemented than those based on other aspects, with the exception of benchmarking, which is extensively implemented (although without differences between the two groups).

To be more specific, no differences have been found in direct costs at a cost system level, that is, measurement systems for packaging purchases and those that measure the economic impact in environmental terms. Packaging purchase costs are usually the most visible and companies are more likely to bear them in mind when measuring the impact of packaging design decisions - they are the most highly scored item by companies in terms of measurement systems. All this explains why the two groups show no significant differences.

At the same time, given that environmental cost assessment tends to focus on the economic assessment of green dot compliance, which is a legal obligation, it also seems reasonable that no differences were found in this aspect. Indeed, this result is coherent with the fact that no significant differences were found in the application of legal design requirements.

Likewise, in most systems based on indirect costs, differences were only found in internal logistics costs (handling, storage and transport). The fact that there are no differences between the two groups of companies in other indirect costs (such as packing or external logistics) could be explained in other ways. On the one hand, packing costs tend to be present and visible in all manufacturing companies (packers), as this is the profile of the analyzed companies. In fact, it is the second most highly scored system. On the other hand, external logistics costs are less visible or obvious and this is coherent, for example, with the similar level of coordination and collaboration found in companies at the end of the supply chain, retailers.

If the analysis shifts to other measurement systems with non-cost criteria, as already mentioned, there are significant differences in most of the systems analyzed. This could be explained because companies that want better results in terms of sustainability do not only develop and implement cost-based measurement models but they also complement those with other systems that use either non-economic qual- 
itative and/or quantitative variables (e.g., LCA or Packaging Scoreboard), or different software tools, which may generate a heightened sensitivity towards deployment of systems capable of identifying future opportunities and needs in packaging (monitoring systems).

\section{Standardization best practices}

As mentioned previously, creating an efficient packaging process demands correct, systematic standardization of documentation, information and criteria. So, from among the four best practices under consideration here, the two more complex ones show significant differences (see table 3 ): in design process documentation (naming those responsible, tasks and deadlines) and in application of the AECOC RAL logistics recommendations.

However, the more basic best practices (palletization documents and materials specifications), which provide supporting information for decision-making, show no differences between the two groups of companies. It should be noted that both of these best practices scored highest within their category.

Table 3 Analysis of the relationship between sustainable performance and the promotion of best practices in packaging design

\section{Pro-active best practices}

Regarding the selection of 11 best practices in this category, we have identified significant differences in eight items (see table 3), including those that were scored highest in the companies: format and materials standardization, aesthetic changes and dimensional changes. Likewise, a positive impact was also found in fostering changes linked to overpacking reduction, materials selection, the packing process and returnable packaging. This means that promotion of almost all types of changes is greater in the group of companies with better performance.

In all events, each of these changes should not be promoted individually in isolation if a global positive impact is being sought. In order to produce such an impact the promotion of changes should be able to feed back on itself and be done in coordination with the other three categories of best practice.

\begin{tabular}{|c|c|c|c|c|}
\hline $\begin{array}{l}\text { Best practice type } \\
\text { (question) }\end{array}$ & Best practice & $\begin{array}{c}\text { Mean "Best Compa- } \\
\text { nies" }\end{array}$ & $\begin{array}{c}\text { Mean "Worst Com- } \\
\text { panies" }\end{array}$ & p-value \\
\hline \multirow{6}{*}{$\begin{array}{l}\text { Structuring best } \\
\text { practices } \\
\text { (What level of coor- } \\
\text { dination is achieved, } \\
\text { internally/external- } \\
\text { ly, in order to search } \\
\text { for more sustainable } \\
\text { packaging?) }\end{array}$} & $\begin{array}{l}\text { Internal coordination in } \\
\text { packaging design }\end{array}$ & 3.889 & 3.600 & 0.1111 \\
\hline & $\begin{array}{l}\text { Integration of packaging } \\
\text { and product design }\end{array}$ & 4.067 & 3.711 & 0.0744 \\
\hline & $\begin{array}{l}\text { Coordination with pack- } \\
\text { aging suppliers }\end{array}$ & 3.556 & 3.089 & $0.0415^{*}$ \\
\hline & Coordination with retailers & 3.156 & 2.867 & 0.1538 \\
\hline & $\begin{array}{l}\text { Coordination with raw } \\
\text { materials/components } \\
\text { suppliers }\end{array}$ & 3.167 & 2.472 & $0.0017^{* *}$ \\
\hline & $\begin{array}{l}\text { Coordination with other } \\
\text { companies to make joint } \\
\text { purchases for packaging }\end{array}$ & 2.556 & 1.950 & $0.0162 *$ \\
\hline
\end{tabular}




\begin{tabular}{|c|c|c|c|c|}
\hline \multirow{11}{*}{$\begin{array}{l}\text { Measurement best } \\
\text { practices } \\
\text { (Has your company } \\
\text { developed a measure- } \\
\text { ment system for as- } \\
\text { sessing different pack- } \\
\text { aging alternatives?) }\end{array}$} & Packaging purchases costs & 4.378 & 4.222 & 0.1631 \\
\hline & Packing costs & 3.956 & 3.844 & 0.2361 \\
\hline & Internal logistic costs & 3.933 & 3.533 & $0.0239^{*}$ \\
\hline & External logistic costs & 3.444 & 3.044 & 0.0799 \\
\hline & Packaging waste costs & 3.556 & 3.333 & 0.2033 \\
\hline & Packaging Scorecard & 1.742 & 1.486 & $0.0441^{*}$ \\
\hline & $\begin{array}{l}\text { Life Cycle Assessment } \\
\text { (LCA) }\end{array}$ & 2.303 & 1.727 & $0.0359^{*}$ \\
\hline & Benchmarking & 3.294 & 2.923 & 0.1048 \\
\hline & "Palletization Software" & 2.658 & 2.049 & 0.0119* \\
\hline & $\begin{array}{l}\text { "Space Management } \\
\text { Software" }\end{array}$ & 2.564 & 1.553 & $0.0004 * *$ \\
\hline & $\begin{array}{l}\text { Monitoring system for } \\
\text { redesigning packaging }\end{array}$ & 3.051 & 2.452 & $0.0044 * *$ \\
\hline \multirow{4}{*}{$\begin{array}{l}\text { Standardization best } \\
\text { practices } \\
\text { (Has your company } \\
\text { developed any of the } \\
\text { following best prac- } \\
\text { tices in packaging de- } \\
\text { sign?) }\end{array}$} & $\begin{array}{l}\text { Documentation of the } \\
\text { packaging design process }\end{array}$ & 3.341 & 2.805 & $0.0360^{*}$ \\
\hline & $\begin{array}{l}\text { Documentation of pal- } \\
\text { letization and packaging } \\
\text { patterns }\end{array}$ & 3.902 & 3.410 & 0.1105 \\
\hline & $\begin{array}{l}\text { Packaging materials spec- } \\
\text { ifications }\end{array}$ & 3.881 & 3.395 & 0.0523 \\
\hline & RAL adoption & 3.906 & 3.321 & $0.0169^{*}$ \\
\hline \multirow{11}{*}{$\begin{array}{l}\text { Active best practices } \\
\text { (Has your company } \\
\text { developed any of the } \\
\text { following changes/ } \\
\text { innovations for im- } \\
\text { proving packaging } \\
\text { desion?) }\end{array}$} & $\begin{array}{l}\text { Materials Standardiza- } \\
\text { tion }\end{array}$ & 3.978 & 3.356 & $0.0019 * *$ \\
\hline & $\begin{array}{l}\text { Dimensional Standardi- } \\
\text { zation }\end{array}$ & 3.844 & 3.267 & $0.0087 * *$ \\
\hline & Aesthetic changes & 3.800 & 3.341 & $0.0404 *$ \\
\hline & Dimensional changes & 3.667 & 3.067 & $0.0089^{* *}$ \\
\hline & Overpacking reduction & 3.533 & 2.837 & $0.0061 * *$ \\
\hline & Material changes & 3.289 & 2.867 & $0.0440 *$ \\
\hline & $\begin{array}{l}\text { Amount of product per } \\
\text { packaging }\end{array}$ & 3.222 & 2.889 & 0.1050 \\
\hline & $\begin{array}{l}\text { Change in the number of } \\
\text { items per each level of } \\
\text { packaging }\end{array}$ & 3.200 & 2.956 & 0.1658 \\
\hline & $\begin{array}{l}\text { Change in packing pro- } \\
\text { cess }\end{array}$ & 3.156 & 2.667 & $0.0369^{*}$ \\
\hline & $\begin{array}{l}\text { SRPs (Shelf Ready Pack- } \\
\text { aging) }\end{array}$ & 2.684 & 2.405 & 0.3300 \\
\hline & Returnable packaging & 2.364 & 1.810 & $0.0300 *$ \\
\hline
\end{tabular}




\section{Discussion}

Packaging's many facets, not just in terms of varied design requirements but also the many viewpoints of the areas, departments and companies involved, would seem to call for careful attention to be paid to the structuring and organization of the design process. The current volatile global context not only demands clear steps towards the deployment of sustainability but also creates threats and opportunities in many fields (for example, new packaging materials or new packing equipment or technologies.

This structuring of the design process could be assisted by identifying, adapting and implementing a series of organizational best practices that help to integrate the product-packaging-supply chain threesome into SPL implementation efficiently and sustainably. Thus, this paper has gone beyond theory (identifying 32 best practices, grouped into four categories) to analyze the relationship between better implementation of those practices and improvement in sustainable performance. So, the study of cleaning and perfumery products has validated the positive relationship in over half of the best practices under consideration $(18 ; 56.25 \%)$. This can be seen especially:

- With promotion and coordination that is vertical (with other companies upstream in the chain) and horizontal (with other companies, even the competition).

- With deployment of assessment systems for alternatives that consider internal logistics costs (of great importance in a global supply chain context) and combine other qualitative/quantitative parameters.

- With the implementation of monitoring systems to identify opportunities that could be applied to packaging.

- With the development of documentation that explains how the design process will be done, detailing not only those responsible, their tasks and deadlines but also the information that will be needed.

- With adoption of parameters or technical recommendations for packaging design (RAL).

- With promotion of changes and innovations in packaging, particularly those focusing on standardization, aesthetic changes, dimensional changes, reduction in overpacking and materials changes.

However, the study has also highlighted how each best practice may not work in isolation (or when applied indiscriminately) and should preferably be linked to others to develop an ecosystem of knowledge and awareness that can turn a supply chain into a learning organization in the packaging design field.
Thus, for example, there is no use in promoting documentation of the design process itself when there has not already been internal/external integration or when there is no objective system for assessing the alternatives. Logically, if companies do not see and measure the impact of packaging design on sustainability, we could understand why companies with do not promote effective changes and innovations in packaging. Neither is it useful to promote a specific design change if there is no understanding of how it will affect each and every stage of the chain

Examples of some of these changes and their impact can be found in the literature. These examples usually focus on large companies (for example, Hellström and Nilsson, 2011; Pålsson et al., 2013; García-Arca et al., 2014; Sohrabpour et al., 2016; Hellström and Olsson, 2017). However, it is not so common that these examples focus on Small and Medium-sized Companies (SMEs). In this sense, ECOEMBES, the main Spanish organization that manages "Green Dot" application, shows some packaging changes applied to SMEs (www.ecoembes.es) and this would be an interesting line for future research.

What the study does give is a "snapshot" of how some best practices impact on sustainable performance, although it does not analyze the paths they have taken to reach these proposals. Such an evolutionary analysis would explain, to a greater extent, the difficulties in developing some of these best practices and would provide a complementary viewpoint to future research.

The main limitations of the paper are the subjectivity of the companies' assessments, the small number of companies included in research, its analysis in one specific sector (perfumery and cleaning products) and the fact that it only shows the manufacturers' perspective on supply chain performance. The profile of the person interviewed could also present some bias towards production and logistics issues linked to packaging, limiting other perspectives such as the commercial viewpoint. At the same time, the paper has considered the "best" companies to be those with the higher sum in the supply chain "performance" items, and not each one independently. All these limitations should be taken into account in future research.

In all events, the authors consider that the approach proposed in the paper may be of interest to both researchers and companies. The contents and results can help both to improve their understanding and knowledge of how the product-packaging-supply chain relationship works when the aim is to improve sustainable performance. Thus, researchers have potential lines for more in-depth research into the quantitative relationship between the structuring of the packaging design process and how this promotes sustainability. The companies, meanwhile, can gain organizational recommendations that will allow them to orient policies and strategies applied to the packaging design process in order 
to improve overall sustainable performance. What is more, its applicability in business and its academic appeal imply that the aim of this research could trigger more intense joint collaboration between researchers and companies, in which the "Case Study" or "Action Research" methodologies can be used (Näslund et al., 2010; García-Arca et al., 2018, 2).

\section{Conclusions}

Implementation of a suitable packaging design process is a key element in ensuring proper functioning of the supply chain not only in terms of efficiency but also globally in terms of sustainability and competitiveness. However, the multi-functional nature of design calls for deployment of some rules, recommendations or considerations (organizational best practices) to assist and guide the process within the development of a Sustainable Packaging Logistics (SPL) approach.

Thus, the main research question of the paper (to explore to what extent the promotion and implementation of organizational best practices in packaging design, framed in an SPL approach, actively contribute to improving the sustainable performance of the supply chains) has been developed and, to a great extent, validated.

This paper may be of interest to both researchers and companies, as the results can aid them in improving their organizational vision of product-packaging-supply chain design in order to improve overall sustainable performance.

\section{References}

Accorsi, R., Cascini, A., Cholette, S., Manzini, R. and Mora, C. (2014), "Economic and environmental assessment of reusable plastic containers: a food catering case study", International Journal of Production Economics, 152, 88-101.

Albrecht, S., Brandstetter, P., Beck, T., Fullana-Palmer, P., Grönman, K., Baitz, M. and Fischer, M. (2013), “An extended life cycle analysis of packaging systems for fruit and vegetable transport in Europe", The International Journal of Life Cycle Assessment, 18 (8), 1549-1567.

AECOC, (2012). "Recomendaciones AECOC para la Logística. Unidades de carga eficientes". Edited by AECOC, Barcelona (Spain).

Azzi, A., Battini, D., Persona, A. and Sgarbossa, F. (2012). "Packaging design: general framework and research agenda". Packaging Technology and Science, 25 (8): 435-456.
Bertoluci, G., Leroy, Y. and Olsson, A. (2014), "Exploring the environmental impacts of olive packaging solutions for the European food market", Journal of Cleaner Production, 64, 234-243.

Beske, P. and Seuring, S., (2014). "Putting sustainability into supply chain management", Supply Chain Management: An International Journal, 19 (3), 322-331.

Bramklev, C. (2009), “On a proposal for a generic package development process", Packaging Technology and Science, 22, 171-186.

Brundtland, G.H. (1987). "Our Common Future (Brundtland Report)", United Nations: New York, NY, USA.

Chan, F.T.S., Chan, H.K. and Choy, K.L. (2006), “A systematic approach to manufacturing packaging logistics", International Journal of Advanced Manufacturing Technology, 29 (9-10), 1088-1101.

Christopher, M. (2016). "Logistics \& supply chain management", Pearson, UK.

Davies, A.J. and Kochlar, A.K. (2002), "Manufacturing best practices and performance studies: a critique", International Journal of Operations and Production Management, 22 (3), 289-305.

European Commission (1994), Directive 94/62/EC on Packaging and Packaging Waste.

European Commission (2004), Directive 2004/12/EC on Packaging and Packaging Waste.

García-Arca, J. and Prado-Prado, J.C. (2008), "Packaging design model from a supply chain approach", Supply Chain Management: An International Journal, 13 (5), 375-380.

García-Arca, J., González-Portela Garrido, A. T. and Prado-Prado, J.C. (2013). "Packaging as support of efficiency and sustainability in supply chain. An applied approach”, Dirección y Organización (DyO), 51, 33-43.

García-Arca, J., Prado-Prado, J.C. and González-Portela Garrido, A.T. (2014). "Packaging logistics": promoting sustainable efficiency in supply chains. International Journal of Physical Distribution and Logistics Management, 44 (4): 325 - 346.

García-Arca, J., González-Portela Garrido, A. T. and Prado-Prado, J.C. (2016;1). "Implementing "sustainable packaging logistics". An analysis in liquid detergents", Dirección y Organización (DyO), 60, 47-56. 
García-Arca, J., González-Portela Garrido, A. T. and Prado-Prado, J.C. (2016;2). "Packaging Logistics" for improving performance in supply chains: the role of meta-standards implementation. Production, 26(2), 261272.

García-Arca, J., González-Portela Garrido, A.T. and Prado-Prado, J. C. (2017). "Sustainable Packaging Logistics. The link between Sustainability and Competitiveness in Supply Chains". Sustainability, 9 (7): 1-17.

García-Arca, J., González-Portela Garrido, A.T. and Prado-Prado, J. C. (2018; 1). "The Importance of Measurement Systems in the Search for Suitable Packaging Options" in Closing the Gap Between Practice and Research in Industrial Engineering, 169-176. Edited by Springer.

García-Arca, J., Prado-Prado, J. C., Fernández-González, A.J. (2018; 2) "Integrating KPIs for improving efficiency in road transport", International Journal of Physical Distribution \& Logistics Management, 48 (9), 931-951

Gelici $\square$ Zeko, M. M., Lutters, D., Klooster, T. R., and Weijzen, P. L. G. (2012). "Studying the influence of packaging design on consumer perceptions (of dairy products) using categorizing and perceptual mapping”. Packaging Technology and Science, 26(4), 215-228.

Grönman, K., Soukka, R., Järvi-Kääriäinen, T., Katajajuuri, J.-M., Kuisma, M., Koivupuro, H.-K., Ollila, M., Pitkänen, M., Miettinen, O., Silvenius, F., Thun, R., Wessman, H. and Linnanen, L. (2013). "Framework for Sustainable Food Packaging Design”. Packaging Technology and Science, 26: 187-200.

Hayes, R.H. and Wheelwright, S.C. (1984), Restoring Our Competitive Edge: Competing Through Manufacturing, John Wiley, NY.

Hellström, D. and Saghir, M. (2007), "Packaging and logistics interactions in retail supply chains", Packaging Technology and Science, 20, 197-216.

Hellström, D., Nilsson, and F. (2011). "Logistics-driven packaging innovation: a case study at IKEA". International Journal of Retail \& Distribution Management. 39 (9): 638-657.

Hellström, D. and Olsson, A. (2017). "Managing packaging design for sustainable development", Wiley, London.

ISO (2006). "ISO 14040: 2016. Environmental management. Life Cycle Assessment. Principles and framework". Edited by ISO, Geneve.
ISO (2012). "ISO 3676: 20112. Complete, filled transport packages and unit loads. Unit load dimensions". Edited by ISO, Geneve.

ISO (2012). "ISO 3394: 20112. Packaging. Complete, filled transport packages and unit loads. Dimensions of rigid rectangular packages". Edited by ISO, Geneve.

Klevas, J. (2005), “Organization of packaging resources at a product-developing company", International Journal of Physical Distribution and Logistics Management, 35 (2), 116-131.

Kye, D., Lee, J. and Lee, K. (2013). The perceived impact of packaging logistics on the efficiency of freight transportation (EOT). International Journal of Physical Distribution \& Logistics Management, 43 (8): 707 - 720.

Lee, S.G. and Lye, S.W. (2003), “Design for manual packaging”, International Journal of Physical Distribution and Logistics Management, 33 (2), 163-189.

Lindh, H., Williams, H., Olsson, A., and Wikström, F. (2016). "Elucidating the Indirect Contributions of Packaging to Sustainable Development: A Terminology of Packaging Functions and Features". Packaging Technology and Science, 29: 225-246.

Mejías. A.M., Paz, E., and Pardo, J.E., (2016) "Efficiency and sustainability through the best practices in the Logistics Social Responsibility framework", International Journal of Operations \& Production Management, 36 (2), 164-199,

Mollenkopf, D., Stolze, H., Tate, W.L. and Ueltschy, M. (2010), "Green, lean and global supply chains", International Journal of Physical Distribution and Logistics Management, 40 (1-2), 14-41.

Molina-Besch, K. and Pålsson, H. (2014). "Packaging for Eco-Efficient Supply Chains: Why Logistics Should Get Involved in the Packaging Development Process". Sustainable Logistics (Transport and Sustainability), 6: $137-163$.

Näslund, D., Kale, R. and Paulraj, A. (2010), “Action research in supply chain management - a framework for relevant and rigorous research", Journal of Business Logistics, 31 (2), 331-355.

Olander-Roese, M. and Nilsson, F. (2009). "Competitive advantages through packaging de-sign- prepositions for supply chain effectiveness and efficiency". International Conference on Engineering Design, ICED 2009, Stanford University, Stanford, CA, pp. 279-290. 
Olsmats, C. and Dominic, C. (2003). "Packaging scorecard - a packaging performance evaluation method". Packaging Technology and Science, 16 (1): 9-14.

Pagell, M. and Wu, Z. (2009), "Building a more complete theory of sustainable supply chain management using case studies of 10 exemplars", Journal of Supply Chain Management, 45 (2), 37-56.

Pålsson, H. and Hellström, D. (2016). "Packaging logistics in supply chain practice - current state, trade-offs and improvement potential". International Journal of Logistics Research and Applications, 19 (5): 351-368.

Pålsson, H. (2018), "Packaging Logistics. Understanding and managing the economic and environmental impacts of packaging in supply chains", Kogan Page, London.

Rundh, B. (2016), "The role of packaging within marketing and value creation", British Food Journal, 118 (10), 2491-2511.

Regattieri A., Santarelli G. and Piana F. (2019), "Packaging Logistics". In: Zijm H., Klumpp M., Regattieri A., Heragu S. (eds) Operations, Logistics and Supply Chain Management. Lecture Notes in Logistics. Springer, Cham.
Saghir, M., (2002). "Packaging Logistics Evaluation in the Swedish retail supply Chain". Edited by Lund University (Sweden).

Sohrabpour, V., Oghazi, P. and Olsson, A. (2016). An Improved Supplier Driven Packaging Design and Development Method for Supply Chain Efficiency. Packaging Technology and Science, 29: 161-173.

Svanes, E., Vold, M., Møller, H., Pettersen, M.K., Larsen, H. and Hanssen, O.J. (2010), "Sustainable packaging design: a holistic methodology for packaging design", Packaging Technology and Science, 23 (3), 161-175.

Verghese, K., Lewis, H., Lockrey, S., and Williams, H. (2015). "Packaging's Role in Minimizing Food Loss and Waste Across the Supply Chain". Packaging Technology and Science, 28: 603-620.

Vernuccio, M., Cozzolino, A. and Michelin, I.L. (2010), “An exploratory study of marketing, logistics, and ethics in packaging innovation", European Journal of Innovation Management, 13, 333-354.

Wever. R and Vogtländer, J. (2013), “Eco $\square$ efficient Value Creation: An Alternative Perspective on Packaging and Sustainability", Packaging Technology and Science, 26 (4), 229-248. 